\title{
Belgeo
}

Revue belge de géographie

$1 \mid 2019$

Miscellaneous

\section{Social capital in rural development projects in Europe - Three LEADER cases in Wallonia analysed}

Le capital social dans les projets européens de développement rural - Analyse de trois cas d'études LEADER en Wallonie

\section{Marie Permingeat and Dominique Vanneste}

\section{(2) OpenEdition}

\section{Journals}

Electronic version

URL: http://journals.openedition.org/belgeo/34979

DOI: 10.4000/belgeo.34979

ISSN: 2294-9135

\section{Publisher:}

National Committee of Geography of Belgium, Société Royale Belge de Géographie

\section{Electronic reference}

Marie Permingeat and Dominique Vanneste, « Social capital in rural development projects in Europe Three LEADER cases in Wallonia analysed », Belgeo [Online], 1 | 2019, Online since 25 June 2019, connection on 07 July 2020. URL : http://journals.openedition.org/belgeo/34979 ; DOI : https:// doi.org/10.4000/belgeo.34979

This text was automatically generated on 7 July 2020 .

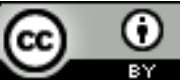

Belgeo est mis à disposition selon les termes de la licence Creative Commons Attribution 4.0 International. 


\section{Social capital in rural development projects in Europe - Three LEADER cases in Wallonia analysed}

Le capital social dans les projets européens de développement rural - Analyse de trois cas d'études LEADER en Wallonie

Marie Permingeat and Dominique Vanneste

\section{Introduction}

1 While rural areas in Europe represent more than 91\% of the territory, $58 \%$ of the people and $56 \%$ of jobs (DG Agri, 2017), stereotypes that stand for "rurality" tend to be homogeneously fatalistic and to refer to poor hinterlands, the hackneyed practice of farming, and exodus and tradition (Reissman, 1964; Lhermite, 2000). Even if those representations are accurate, they are also incomplete, for today's rurality brims with experiments and innovative practices (Village Magazine, 2015; Jouen et al., 2010) instigated by rural dwellers and communities themselves, and by newcomers linked with reverse urbanization (ENRD \& EC, 2010; Doré, 2011).

2 Rural development was one of the hot topics of 2017 European politics. With the reform of the Common Agricultural Policy (CAP), the intensifying discourse on food quality and the debate on paradigm shift, turning to rural areas for answers and experimentations seems to have become mainstream (Oakley, 1991; Pike et al., 2010). These areas' potential has been formally explored since 1991 at the hand of the LEADER approach - "Liaison Entre Actions de Développement de l'Economie Rurale" - which upholds endogenous development by funding bottom-up initiatives. Following seven principles - cooperation, networking, innovation, locality, multi-sectorialism, bottomup process, and the drawing of local strategies - the approach is expected to induce the development of territories by their inhabitants themselves and promotes a sense of community (ENRD \& EC, 2012; Doré, 2011). 
3 The hypothesis put forward by LEADER is that the approach gives rise to projects that offer long-lasting solutions to reverse the apparent trend of decreasing vitality of rural areas. Implicitly, by adverting locality as the essence of the approach, it states that local knowledge and capitals, especially social, are core in the success of projects (EENRD \& EC, 2010; Doré, 2011). Yet, those are rarely mentioned in EU-endorsed documents that define the approach. Even if an effort is currently given to try to include the assessment of social capital (SC) in the evaluation of the 2014-20 programming period - in Wallonia for instance - a significant gap exists with the official methodology recommended by the European Network for Rural Development regarding that matter (Pisani, 2017). Likewise, because of a lack of literature on the topic, it is not clear how the seven principles are implemented in the field, how local dwellers are involved and how sustainable - in the sense of lasting - projects turn out to be.

4 Hence, the aim of this paper is to create more insight on the role of social capital in the approach by assessing to what extent it can be considered as a factor of success or failure in the implementation of projects and the concrete role it plays in their perennity, and provide recommendations to assess its role. Therefore, we aim at contributing to the reflection on the involvement of social capital and ways of measuring, monitoring and evaluating. The paper will start unravelling the relationship between LEADER, the CAP, farming and rural development and highlighting the main aspects of the approach that interest us when considering social and human capitals. The methodology used and case studies investigated for the research will then be introduced, before discussing results.

\section{Conceptual Framework}

5 Introduced in 1916 by Hanifan, social capital (SC) is what "in life tends to make tangible substances [real estate, personal property] count for most in the daily lives of a people, namely goodwill, fellowship, mutual sympathy and social intercourse among a group of individuals and families who make up a social unit, the rural community" (Hanifan, 1916, p. 30). The two main contributions to social capital that we will use in the research are the ones of Bourdieu (1986) and Putnam (1995). Both define social capital as what holds societies together, but the main difference in their theory lies in that for Bourdieu, social capital brings benefits to individuals, and its dynamics are influenced by personal connections, trust, reciprocity, dispositions and self-interest. This is a specific type of power which enables people to "accrue material or symbolic benefits" (Levien, 2015). These social networks and connections are constantly evolving and in a "very peculiar movement of re-association and reassembling" (Latour, 2005), which makes them highly difficult to grasp and study. To the contrary, Putnam links SC to civic engagement and explicitly excludes self-interest and people's dispositions (Putnam, 1995) in the dynamics that make SC up. Therefore, Putnam considers that the features of social organization -trust, norms and networks - benefit to the common good. Put in another way, SC theory "refers to the capacity of people to act towards common goals" (Rodriguez-Girón, Vanneste, 2019, p. 24). Although social and human capital are sometimes badly distinguished, human capital is represented by individual skills and education (Bourdieu, 1986), while Coleman (1988) attributes value to social capital in the creation of human capital. According to Huff (2013) human capital includes all the 
knowledge, talents, skills, abilities, experience, intelligence, training, judgement, and wisdom possessed individually and collectively. A parallel can be drawn between social capital defined as networks working towards a common good, and human capital, seen as a collection of traits used to work towards a common goal.

6 The LEADER approach was born in the context of the New Rural Paradigm which is a model of rural development, based on partnership, programming and local participation, aiming at the realization of integrated rural development, in order to achieve a more efficient use of resources and a reduction in regional and social inequalities (OECD, 2006). It lays its foundations on identity-based policies and the use of endemic resources and savoir-faire (EENRD, 2010). Governance is understood as a system of continuous negotiation among nested governmental and non-governmental actors. The process involves the interaction of multiple stakeholders, often with different definitions of the challenges being addressed, working at different political levels, and therefore a multiplicity of values and viewpoints become relevant.

Nested in that paradigm, LEADER rests on the principle of "localities" which states that those differentiate from each other because of territorial capital. This type of capital comprises local traditions, know-how, skills, activities, rules, culture, relationships and cooperation networks (i.e. social capital) and "something in the air", called the "environment" and which is the outcome of a combination of institutions, rules, practices, producers, researchers and policy makers that make a certain creativity and innovation possible" (OECD, 2001, cited by Camagni, 2008, p. 37). Place-specificity implies that (some) local assets "are better suited to the area that uses this potential more effectively. Therefore, territorial development policies should first and foremost help areas to develop their territorial capital" (CEC, 2005, cited by Camagni, 2008, p. 36).

8 As we are investigating the importance of SC in projects, we need to evaluate its involvement during and before the implementation of the project. In theory, and proven in practice (Oakley, 1991; Vanneste, Ryckaert, 2011), a project that promotes participation is very unlikely to arise spontaneously and is mostly introduced and managed by an "external agency". This agency can be a government body or a nongovernmental organisation wherein a main agent operates and acts as a facilitator and catalyst. Working both in a formal and informal way, this "broker" will stimulate trust and dialogue between participants and will know how to provoke debate. The role of an actual "broker" is core when wanting to generate efficient activities that will promote participation (Vanneste et al., 2011). Indeed, his or her professionalism and experience will foster a bottom-up approach in a "more professional, coherent and planned manner" (Vanneste et al., 2011, p. 56) more than an (inexperienced) local is likely to do.

It is further argued that success depends on that agent as "the practice confirms that participation will not evolve at project level unless a number of project staff work exclusively and explicitly on its development" (Oakley, 1991; Gerrets et al., 2015). This is what our investigation will focus on.

\section{From concept to policy}

10 LEADER then acts as a development policy that aims at developing territorial capital. Indeed, the approach was born and included to the EU's set of regional policies in 1991 and later integrated to the Common Agricultural Policy (CAP), as the fourth axis of its 
second pillar - that aims at preserving rural areas and their social life (illustrated in Figure 1). It acts as the methodology to develop its three axis.

Figure 1. Representation of the axes of the second pillar of the CAP.

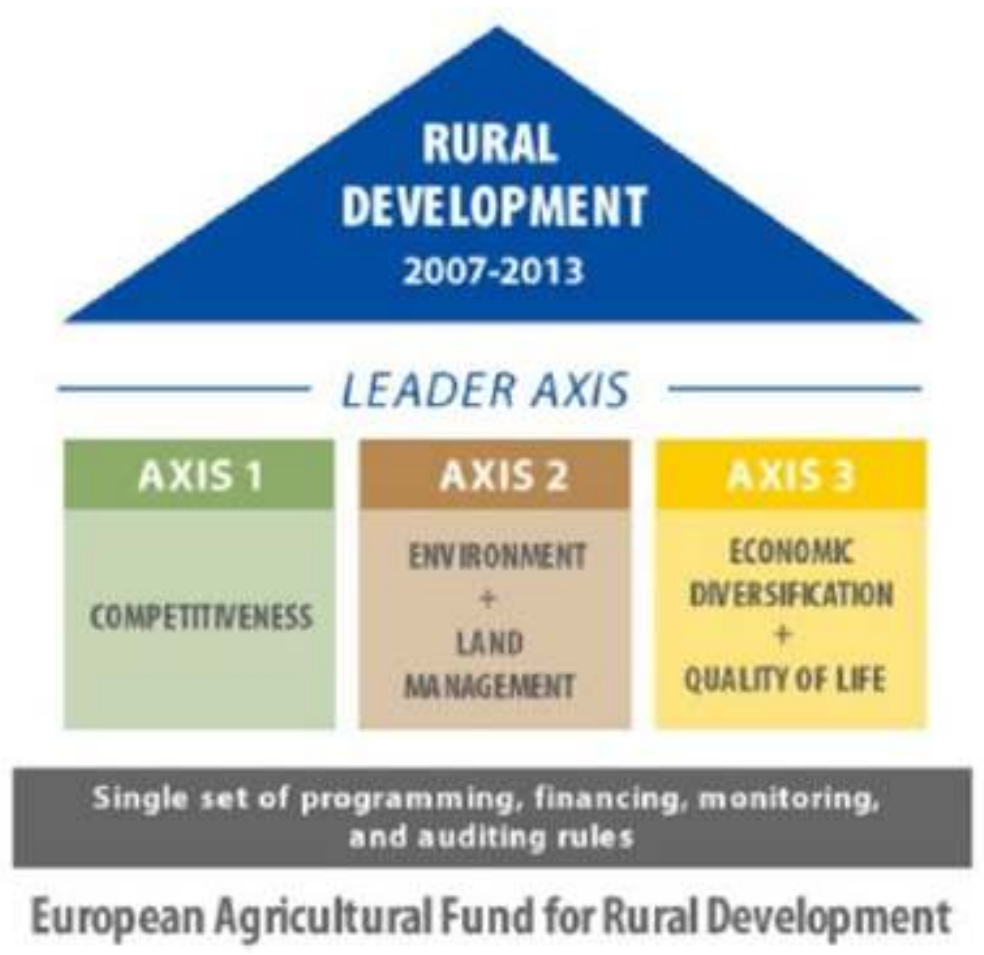

SOURCE: ENRD, 2014

The CAP became at that moment not only a means to ensure food security but to "reverse trends towards economic and social decline and depopulation of the countryside and to enhance the human potential in this respect" as stated in the preamble (paragraph 46) of the European Commission (EC) Council Regulation $\mathrm{N}^{\circ} 1698 / 2005$ (EC, 2005, L277/5). At length, the approach was renamed "LEADER-CLLD (Community-Led Local Development)", as it evolved to enable the multi-funding of single actions and the association of maritime, rural and urban areas in projects (ENRD, 2017), concluding the amalgam between rural development and agricultural policy.

It is important to note that the process of concertation of local actors towards a Local Development Strategies (LDS) conception is different in Wallonia than in the rest of Europe. Indeed, in Europe, when territories answer a call for Local Action Group (LAG) creation, the main dossier they must hand in is their LDS. Specific projects are not included yet as they are to be chosen by the LAG once the programming period starts and the LAG grants its status. In Wallonia, public concertation and calls for projects occur at the moment of drafting the LDS, meaning that when the LDS is handed in, it comes with a set of priorities and projects to be developed that were imagined by the concerted public. The document as a whole is either validated or refused, but once validated, the Walloon public authorities guarantee that all projects will get funded and developed, without exception. Projects deemed not relevant are not included in the LDS. The managing authorities can ask for minor revisions on projects but this does not occur frequently. LAG technicians and members of the Administrative Committee contribute to building projects and orientate the teams to have acceptable projects. 
Each LAG develops 6 or 7 projects per period, which it can manage itself or delegate to a partner (Tourism office, cultural centre etc.). LAGs do not publish calls for projects during the programming period, but rather call for thematic officers to coordinate each project that was decided alongside the LDS. Projects are subject to a sectorial management by administrations directly linked to them (tourism, culture, training, energy...) which devise annual budgets.

Furthermore, when investigating the perception of the EU on social capital in the approach, one can be surprised. The theory behind LEADER's intervention logic is that partnerships and participation "deliver better outcomes and impacts than individual agency work" (ENRD, 2014, p. 21). Yet, social capital is not mentioned in the approach's guidelines for implementation. There, the mere reference to this type of capital is made through promoting networking as the second step to undertake after capacity building, thanks to the organisation of public seminars, workshops or meetings to bring actors together and make them discuss the needs of their area (EC, 2017).

Nevertheless, when reviewing the outputs of the approach in the guidelines for evaluation, four effects on the development of social capital should be checked: 1) an increased trust and mutual support between the managing authority, the paying agency, the natural rural network, Local Action Groups (LAGs) and their beneficiaries, 2) an increased participation of actors in the design and implementation of a bottomup approach, 3) the creation of real partnerships and the sharing of norms and values, and 4) the efficient spread of information between actors through networking (EC, 2017). In this document, the development of social capital comprises social organisation elements that favour coordination and cooperation in a mutual interest, such as networks, norms and trust, therefore using a clear Putnamian vision of social capital that excludes self-interest.

In fact, it is stated in those guidelines that "CLLD is implemented through the adoption of a specific method which, if correctly applied, will create added value, in the form of social capital, better local governance and greater results" (EC, 2017, p. 60). Therefore for the $\mathrm{EC}$, social capital is an output of the approach, but is never formally considered as an input. Likewise, even though the effect of the approach on SC is recognized and asked to be evaluated by the EC, no normalized evaluation method exists. The EC gives several examples for impact indicators such as: increased trust and support, increased participation, increased efficiency and effectiveness of communication, increased ability of actors (information, competences and knowledge), but leaves the choice on outcome indicators at the discretion of LAGs.

This freedom to quantify the changes in social capital is at the heart of the ongoing debate in Wallonia to create a regional norm to evaluate it. Interviewees mention that the organism in charge of the evaluation of the programme - ADE (Aide à la Décision Economique) - considers whether to use or not new technologies and social media as indicators to account for the number of new and perennial networks and social groups that arise during and after the implementation of the strategy (ADE - Head of Rural Development \& Environment Department, personal communication). Facebook pages for new social groups, are considered "family pictures" that illustrate project activities, although influenced by the age gap between people involved in activities (the older) and their usage of social media (the younger) (ADE - Head of Rural Development \& Environment Department, personal communication). 


\section{Methodology and projects}

17 To test the hypothesis that social capital plays a decisive role in the perennity of LEADER projects, three case studies were investigated.

Out of the five existing LEADER programming periods, it was decided to choose cases that were developed between 2007 and 2013, for a balance had to be found between being able to assess perennity and recording the most accurate memories of interviewees.

Reviewing the ex-post evaluation of the Walloon Rural Development Programme (ADE, 2016), projects under this period had been classified into 10 topics, going from heritage preservation to mobility. The "Social Economy" topic was chosen since social economy is a branch of economy that not only aims at creating economic value but also at increasing social inclusion and reducing inequalities (OECD, 2017). Furthermore, it was found interesting to study the real involvement of social capital (SC) in projects within the topic "Social Economy". It seems quite obvious to expect that SC plays a significant role, considering that social economy is supposed to be operated by people for the people, but the implementation is seldom without hurdles.

Four projects were part of this topic: "community houses" (later referred to as project 1), "Social Insertion Farms" (project 2), "From Solitary to Solidary" (project 3), and "Volunteering in rural areas". The four LAG coordinators were contacted to obtain the authorization of studying their projects. Since the coordinator who had overseen the volunteering project was unavailable at the time of research, it was chosen to focus on the three other projects. This still allowed to study the topic as an entity.

21 A more quantitative approach could have been an option. Grootaert et al. (2004) present a way to measure SC in terms of listed variables, including econometric analysis. Nevertheless, we chose a qualitative approach due to the small number of projects and our aim to capture the appreciation of stakeholders. Therefore, we opted for interviews as the main methodology while trying to collect information on the main basic dimensions mentioned by Grootaert et al. (networks, trust and collective action) through their discourse on the development and results of the project. Another reason why we used a qualitative approach had to do with our focus on the process since research reveals that learning and the development of collaboration skills during the elaboration of the project is as important as the outcome (Vanneste, Ryckaert, 2012).

The research unfolded in desk and field study. Documents supplied by the LEADER interface and the LAG's technical teams had provided us with valuable secondary data, comprising a significant amount of information, notably on the composition of groups that participated to the LAGs, the frequency of meetings, the conception of projects, number of participants etc. These documents consisted of the LAG's overall 2007-13 Local Development Strategies (LDS), project-notes (PN), final project reports (FR) and self-evaluation, if existing. Primary data was collected through semi-structured interviews. LAG coordinators, project head-missions, public representatives, external project bearer's representatives and participants to the projects were identified as potential interviewees. 23 actors were contacted but 5 did not respond or interviews did not take place as they had not been involved in the project (ex: current coordinator of a LAG that was not there ten years ago). Finally, we conducted 18 semi-structured interviews with different types of stakeholders (Figure 2) that lasted $30 \mathrm{~min}$. on average 
with a maximum of $1 \mathrm{~h} 12$. Interviewees were either chosen because referred to in LAGs reports or indicated by other interviewees; a list is available in Appendix 1. Interviews were conducted in French and selectively transcribed. The main topics to be discussed during the interview were divided into three parts that would act as a thread (Table 1) but would leave space to adapt to each type of stakeholder. For the people directly involved in the LAG's administrative committee, questions focused more on the conception stage and on the reason why decisions were taken the way they were, while for other stakeholders, we focused more on implementation and on personal satisfaction and perception on how the process unfolded. Keeping in mind that projects were created ten years in amount of our research, interviewees were asked to reflect on the involvement of social capital prior to the interview in order to refresh their memory. The interviewees provided us with qualitative data; approximate quantitative data were used as a complement.

Figure 2. Distribution of stakeholders interviewed.

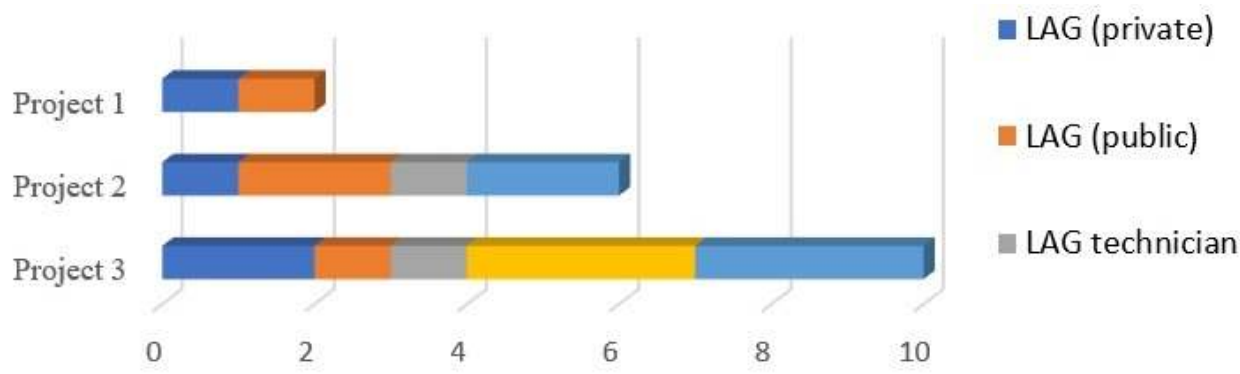

23 Collected primary and secondary data were ordered according to stages in the project development (Table 1) and analysed by crossing the contents of the interviews with the ones of the documents and with elements from SC theory. In the first phase, the attention was given to how the processes unfolded during projects, then on understanding the motivations and conflicts between stakeholders, before crossing and comparing different topics such as networking, which will be at the centre of our discussion.

Table 1. Headlines for interviews.

\begin{tabular}{|c|c|}
\hline \multirow{6}{*}{$\begin{array}{c}\text { Local Development } \\
\text { Strategy and project } \\
\text { conception }\end{array}$} & Diagnosis of the territory: who, how \\
\hline & Composition of the AC and GA: who, how \\
\hline & Definition of the LDS, concertation: who, how and why \\
\hline & $\begin{array}{l}\text { Call for project and project selection, work group } \\
\text { composition }\end{array}$ \\
\hline & Partners planned \\
\hline & Planning perennity \\
\hline \multirow{5}{*}{ Project implementation } & Choosing a coordinator \\
\hline & Division of tasks \\
\hline & Relationship between stakeholders \\
\hline & Key actors \\
\hline & Difficulties and successes \\
\hline \multirow{5}{*}{ Perennity } & $\begin{array}{l}\text { Matching with what was planned? If not, why } \\
\text { Impact on LAG composition }\end{array}$ \\
\hline & Satisfaction and behaviour of all stakeholders involved \\
\hline & New networks and change in overall social dynamic \\
\hline & Impact on LAG composition \\
\hline & Perception of factors of success and failure \\
\hline
\end{tabular}




\section{Projects selected}

Wallonia, the Southern and French-speaking part of Belgium is composed for $88 \%$ of rural areas (ENRD, 2015). The LEADER programme, managed by the Direction des Programmes Européens, is supported by the Walloon Rural Foundation (FRW). The 2007-13 Walloon Rural Development Programmes focused mainly on agri-environment payments and on the modernisation of agricultural holdings. The LEADER axis, with a focus on Quality of Life and diversification (ENRD, 2014), is certainly not the most important one in terms of budget but not negligible if one takes the (possible) nonmonetary input and output into account. LEADER funding amounted to $€ 20.83$ million for 15 LAGs (RWDR, 2011) which represented 5\% of the RDP (period 2007-13), or about $€$ 1.4 million of public funding per LAG (RWDR, 2011). These LAGs covered $12 \%$ of the territory and 35\% of the population (Walstat, 2014 and ADE, 2016, p. 148).

LAG 1 (project 1) (figure 3), the Pays des Tiges et Chavées was created as a collaboration between the municipalities of Gesves and Assesse in 2003 and joined by Ohey in 2008. LAG 2 (project 2), Haute-Sûre Forêt d'Anlier, was created in 2000 and borders the Grand-Duchy of Luxembourg and covered 6 municipalities: Bastogne, Fauvillers, Habay, Léglise, Martelange and Vaux-sur-Sûre. LAG 3 (project 3), Cuestas, was created in 2000. Also located in the south of the Luxembourg province, it is composed of 3 municipalities: Etalle, Meix-devant-Virton and Tintigny.

Population density is lower in the territories studied than in Wallonia: indeed, it amounts to 87 inhabitants $/ \mathrm{km}^{2}$ in LAG 1, 51 in LAG 2 and 56 in LAG 3, while the mean is $208 / \mathrm{km}^{2}$ in Wallonia (Statistics Belgium, 2010), influenced by the urban and industrial concentrations mainly situated in the north of the region. The three territories have been the sites of reverse urbanisation since the 1970s. In LAG 1, this is due to the phenomenon of peri-urbanisation which has been developing from the urban centres of Namur and Liège. Newcomers originating principally from these centres, are people who are more educated than natives of the territory (LAG PTC, 2008). In LAGs 2 and 3, the inflow is due to the proximity of the Grand Duchy of Luxembourg. Immigrants there are also mainly young, educated families attracted a.o. by affordable real estate prices. Yet, a different dynamic there is that $30 \%$ of the territory's locals live alone (LAG Cuestas, 2007). The migration of highly qualified young workers meant an evolution in mean income, which increased in the three territories, highlighting inequalities between newcomers and natives in the areas. This phenomenon induced a rise in real estate value. This, combined with income inequalities resulted in further isolation of modest groups and natives who would either consider moving to urban centres, live in (precarious) enclaves in rural areas (LAG Cuestas, 2007). 
Figure 3. Map of three LAGs and their population density.

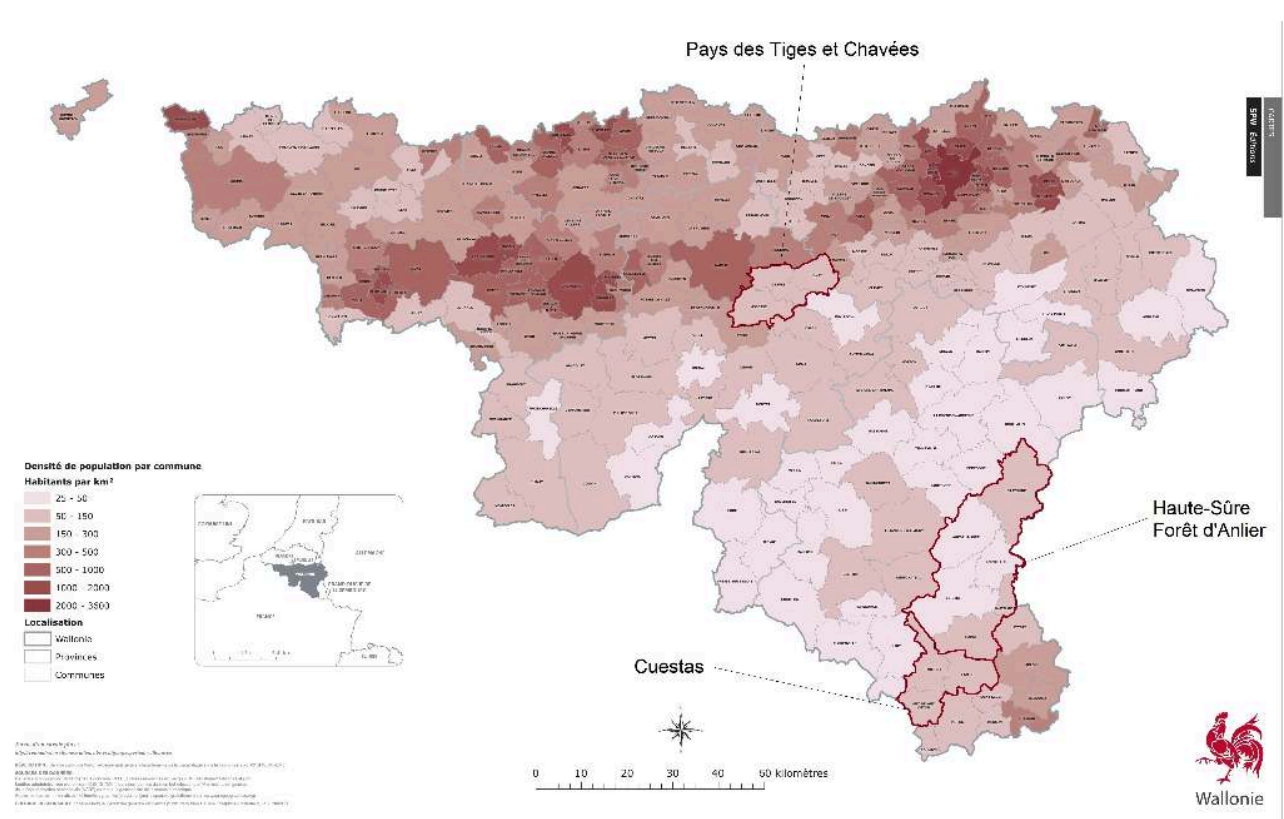

Conception: author - Base map: SPW, 2017, Les 262 Communes de Wallonie et leur densité de population

As for networks, the Local Development Strategy (LDS) of LAG 1 states that, in 2007, the municipalities "were lucky to be able to count on a particularly active associative network" creating a "favourable ground for the activation of social capital through LEADER" (LAG PTCS, 2008, p. 11). Likewise, it is specified that these share a history of collaboration through the organization going from similar political majorities to the organization of common events such as the of a joint annual fauna and flora photo exhibitions. In LAG 2, the LDS does not specify the amount of associations present on the territory, but the review of the municipalities' websites ${ }^{1}$ permitted to itemise more than 345 in the whole territory, quite a significant number. In LAG 3, associations mainly focused on representing youth due to the young component of the population. The LDS mentions the active political support for associations focusing on social support and social reinsertion but data on their existence were not available.

Table 2. Leader Budget (2007-13) per LAG/ project studied.

\begin{tabular}{|l|l|l|}
\hline Project & Budget (total*) & Duration \\
\hline $\begin{array}{l}\text { LAG 1 - Community Help for } \\
\text { Seniors' }\end{array}$ & $186,000.00 €$ & $01 / 01 / 09-30 / 06 / 2015$ \\
\hline $\begin{array}{l}\text { LAG 2 - Social Insertion } \\
\text { Farms }\end{array}$ & $68,900.00 €$ & $01 / 04 / 09-31 / 12 / 2014$ \\
\hline $\begin{array}{l}\text { LAG 3 - From solitary to } \\
\text { solidary }\end{array}$ & $193,000.00 €$ & $01 / 11 / 08-31 / 03 / 12$ \\
\hline
\end{tabular}

*NOTE: IN WALLONIA, LEADER PROJECTS ARE fINANCED 45\% BY THE FEADER, 45\% BY THE REgION AND $10 \%$ BY LOCAL SPONSORS.

Source: respective PNs of the three projects 
Project 1 - LAG 1: "Community Help for Seniors" - It was part of the project note "Proximity Services", which aimed at improving the quality of life of the territory's inhabitants - focusing on elders - and at creating social ties based on solidarity. Concretely, it consists in welcoming the seniors of the territory one day or more per week in a specific and adapted location, to offer them gratifying activities, to prepare and share a convivial lunch, under the supervision of qualified personnel. The aims were to increase the attractiveness of the territory for elders, fight against social isolation, support their relatives, and to advertise community hospitality as a medium between the choice to live in residential facilities for elderly or care at home. The project was introduced and carried by a local association external to the LAG.

Project 2 - LAG 2: Social Insertion Farms - The project's objective was the social reintegration of vulnerable people: would they be young people in a situation of school dropout, adults with light mental disabilities or people in a situation of social isolation. "Social agriculture" - as it is referred to in the northern part of Belgium and existing there on a legal level- was lacking in Wallonia. The idea arose from a local farmer who wanted to be able to offer these services at his farm. Concretely, it consisted of creating partnerships between farms and social institutions, devising a legal framework protecting both parties and raising awareness on the methodology through the editing of a handbook. This was meant to be a pilot project for testing a framework at a local level that could be repeated and extended at regional and then European scales. It was carried out by the LAG itself.

Project 3 - LAG 3: From solitary to solidary - The project's main objective was to change the vision that traditional actors of economic development have of the social and voluntary sector and of their beneficiaries. This went through the constitution of a network of local associations, the improvement of the vision that beneficiaries have of themselves and to give a voice to vulnerable people. Gross initiatives were defined in the LDS but a specific fitting of the chosen topics was expected to arise from the project coordinator and locals. In the end, 16 initiatives were undertaken and included: the creation of a mobile game-truck, the organization of inter-generational events, debates, empowerment workshops for young parents, etc. The project was carried directly by the LAG.

\section{Some results on social capital}

\section{Considerations of authorities on public involvement in Local Development Strategy (LDS) conception}

31 We already know that Wallonia designed a specific process for LAGs to create their LDSs to make sure that social capital would be taken into account. This unfolds as follows: 1) the identification of themes by the Administrative Committee (AC), 2) public concertation to call for projects, 3) constitution of working groups and thematic reflexions, and 4) integration of projects to the LDS.

Yet, in two out of the three cases studied, no new and formal concertation was undertaken in this first step. Indeed, the actors mobilized were already part of LAGs or were directly chosen by them. In all projects, it was considered that the concertation undertaken on the previous programming period(s) and the experience LAGs' staff 
drew from it was enough at least to choose axes to develop. When specific knowledge was required, organizations or professionals were consulted to evaluate the needs of the territory. Those were chosen through word-to-mouth or because they were recognized/famous for their expertise. This has the advantage that one can rely on a firm, existing network but it prevents renewal. A significant example occurred in LAG 1. The two "original" municipalities consulted one person only from the new town that joined the LAG, to participate in the creation of the strategy.

When drafting project-notes (PN), work groups (WG) were involved in the three cases. Yet, differences remain in the way people participated. Indeed, in project 3, partners for participating in a WG and create a PN, were identified directly by the LAG's general assembly, which considered it had sufficient knowledge on its region to know who would be interested and fit for the task. In project 1, the WG that defined the project was constituted by members of the executive non-profit organisation only, plus members of the LAG's AC under their command. It is interesting to note that the project had been suggested by the same organisation, while trust and social links between the organisation and the LAG were openly mentioned as a reason for this structure. In project 2, the group was open to anybody who was interested, which created then a much wider group than in the two other cases, involving 20 farmers. The idea there had been pitched by a local farmer during the previous concertation.

\section{Attention to networks for project implementation}

As mentioned before, in project 1, the relationship between the LAG and the (executive) non-profit organisation seemed to have been normalized through a contract in which the project had been delegated to the non-profit organisation; relationships were formal and financial (CAIAC, coordinator of the project - personal communication). In projects 2 and 3, trust was a major lever but at the same time, two new responsibles were recruited to coordinate the PNs, which we will refer to as "brokers" as defined previously.

Those latter LAGs were conscious of the key role of their brokers, determining the success or failure of the project. What is more, our contact with the Walloon Rural Foundation confirmed the importance attributed to the social aspect in her/his training at the time of recruitment and confirmed that "listening abilities and knowledge in psychology and social aspects had been core" for the decision (Personal communication). These responsible people (brokers, facilitators, coordinators) worked in symbiosis with their work groups, gather core stakeholders to give life to the project and activate the territories' potentialities. Hence, these LAGs dedicated effort to hire the most fit personnel for the task: "LEADER funding is about funding brains, not furniture, material etc. Hence it is extremely important that the team is coherent. We do significantly check the applicants" (Cuestas LAG president 2007-13, Personal communication). LAG 3 ensured that this person would fit with the team by submitting him to a personality test, and LAG 2 recruited theirs from a list of established characteristics - having worked in the social sector, being benevolent and caring, for instance. LAG 3's coordinator confirmed himself involvement was particularly significant: "it was a job in which I was feeling good; maybe people were feeling that and that is why it became a strength" (personal communication). LAG 3's broker managed to activate the territory's potentialities when not even being a native: he 
moved to the region when recruited for the project. Yet, he was very quickly respected because "he behaved as a neutral party, and was able to establish an extremely easy contact with youth" (Cuestas LAG president 2007-13, Personal communication).

The networks used by LAG1 were already perennial and had apparently proven conclusive on the previous period, while LAG 2 and 3 let the choice of networks used, to the coordinator (broker, facilitator) as the trusted person with specific human characteristics. This was clearly visible when studying the actors' interests and influence in the three projects. In project 2 and 3 these two brokers operated through word-of-mouth to contact potential partners of the project or find initiative bearers. The coordinator of project 3 constituted a network of people to help him to voluntarily organize events and initiatives. This network was so strong that when the broker was on holidays, he could always count on someone to watch over the initiatives in place. In project 2, using traditional networks (public directories, associations of farmers etc.) failed to stimulate the project. The coordinator witnesses: "I sent letters to all the farmers in the region. Out of 580 , two contacted me, including one that was interested only by the "cheap workforce" aspect... It is the word-to-mouth that really worked" (Personal communication). In other words, what worked was informal communication: reaching individuals through other working groups within the LAG, building personal connections, out-of-school conversations with mothers etc.

The significance of networks is also linked with what did not occur. Indeed, several actors mention the frequent switch of actors from associations, implying that representatives tended to change quite often, at least within the time scale of the LEADER projects. The same goes for policy makers, recalling the limitation of the length of policy mandates in a democracy. When a person who was actively involved in a project stopped working with it, this explicitly harmed the initiative.

\section{Strategy to ensure perennity}

38 Even though LEADER projects are supposed to be experimental, it is interesting for LAGs to plan their self-sufficiency post funding and see if it is viable in time. Each LAG had a different vision of sustainability: LAG 1 looked for ways to make it lasting financially, as funding was considered to be the main lever to ensure sustainability. It was interesting to note there that the non-profit association in charge considered the LAG mainly as a money provider and insisted on remaining -autonomously- in charge. Some disagreements were noted on that topic as the LAG wished to be more involved. LAG 2, on the contrary, privileged empowering people. It made a point bringing together individuals who wanted to develop the same initiative and providing support to educate those groups - by the creation of a guidebook, workshops etc. while - until today - remaining available to share its experience. It also actively lobbied for the transfer of their initiative to the regional level, which succeeded. Here again, the role of the coordinator (broker) was essential in creating this dynamic. Project 3 stopped due to a lack of political will as explained previously, and was let to the initiatives of volunteers, who, lacking coordination skills and a stimulating person in charge, gradually lost their sense of involvement and dynamism. Even before the end of the funding, as they were witnessing the change of political will, they stopped trusting authorities for support. Indeed project 3's initiator stated that "when we saw that the 
Administrative Committee did not believe in the project any more,... it is then that the fragility appeared" (personal communication).

\section{Social capital indicators: a summary}

39 We stated before that we didn't intend to "measure" SC in a quantitative way but by recalling reports and interviews, we tried to check for the presence or absence of a number of SC "variables", based on Grootaert et al. (2004) while trying to analyse the discourse of the respondents on the development of the projects (Table 3 ).

Table 3. Basic dimensions of Social Capital for 3 LEADER projects in Wallonia Belgium.

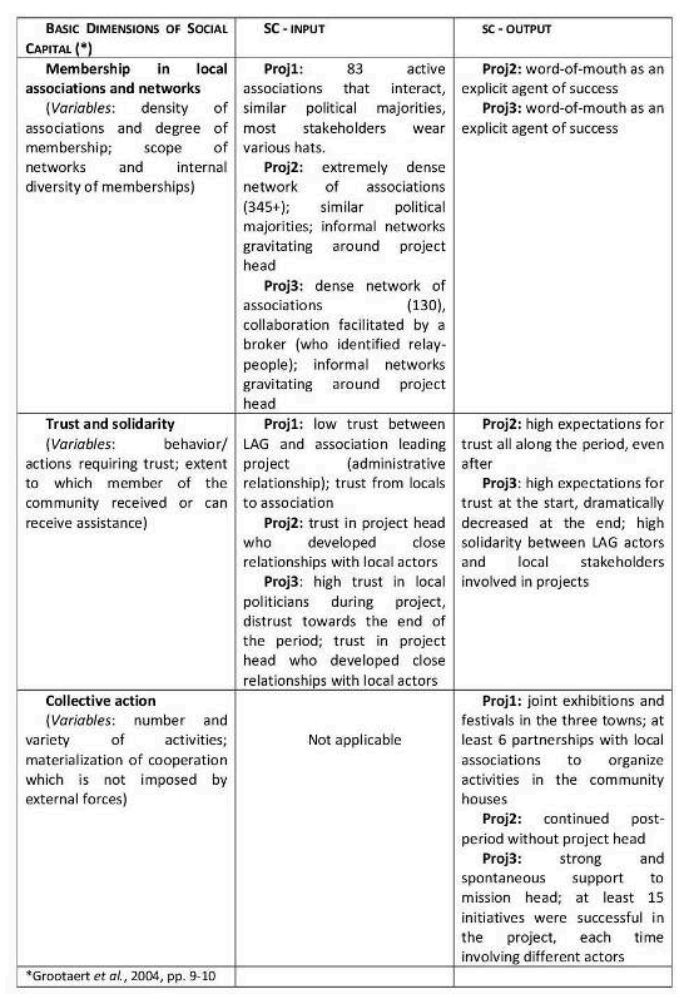

SOURCE: 18 FACE-TO-FACE INTERVIEWS, 2017

Table 3 gives an overview of SC variables in relation to the three cases analysed. It highlights the fact that the success of the projects highly depended on a territory's ability to connect actors together and activate their potential, by trusting a broker's personality and capacity to conduct a project. Building close relationships and friendships with locals - which did not always occur - ensured solidarity and guaranteed spontaneous collective action.

\section{Discussion and conclusions}

41 In theory, we saw that the EC had a Putnamian vision of social capital, excluding people's self-interest. Yet, politics played significant roles in all projects in different ways. They directly affected the perennity of project 1 - the majority of one municipality was not the same than in the two other ones, impeding the project from 
the start - and in project 3 they provoked discontent among various actors since the majority was reversed at the end of the programming period and the new policymakers focused their efforts on a different territorial strategy. For project 2, we have a positive outcome since project 2 was successfully transferred to regional level. The fact that a member of the cabinet in charge of agriculture and rurality decided to include social farming as one of the new measures of the new Regional Development Programme (measure 16.9 about the "Diversification of agricultural and forestry activities in the health sector") is not without significance. The fact that some actors get different hats - politician, president of an organisation in charge of implementation, member of the Administrative Committee - sometimes jeopardized the role of the LAG, in which politics are not supposed to play a role (Martínez Arroyo et al., 2015). These confusions make it difficult to understand if a person pushed a project as a politician or as part of an organization or as a member of an informal network, and on what grounds or interests he/she decided to act. In any event, political will had direct consequences on the perennity of the projects.

When investigating on social capital, it became quite clear that the relationship between social capital and human capital played a core role in two of our projects and explicitly contributed to their success. It is interesting to see that these two capitals can and should be superimposed, assuming that social capital is constituted on a subordinate level by a myriad of human capitals. At least, where human capital was used to capitalize on social capital, the projects were more successful. Indeed, in LAGs 2 and 3, more than social capital, these LAGs looked directly into human capital, as intertwined with social capital through constant interaction, and they were aware of it. Through direct contact with partners and potential beneficiaries, they managed to activate the pre-existing potential of the territories. We do not know if projects could have arisen without these agents, but we can for sure confirm that participation evolved thanks to staff working explicitly on it, confirming Oakley and Grootaert's researches (Oakley, 1991; Grootaert, 2001). One can wonder why social capital and its relation with human capital are not more emphasized by the EC when it comes to writing guidelines for implementation or evaluation of project proposals. Nevertheless, we witnessed in our projects that it is understandable that no outcome is provided by the EC to measure the change in social capital given that numbers (quantitative outcomes) might not be significant and dependent on the kind of LAG. Yet, a system could be implemented and normalized in LAGs to measure at least the baseline social capital, especially the outcome of activities undertaken, along with a qualitative appreciation system that reveals learning processes and (collective) initiatives of any kind. It is recommended to underline (more) the need for an effort to formalize the role of social and human capital in policy documents and proposals, and to encourage LAGs to truly dedicate time to build networks, trust and choose the right brokers at the start of every programming period.

43 The latter reflexion raises the paradox of promoting bottom-up projects through a topdown approach. Incidentally, this paradox was quite evident in the projects studied and in the Walloon approach to Local Development Strategy creation. LEADER, as an approach that promotes self-initiatives, autonomy, bottom-up implementation and creation of project, was there almost entirely driven by actors that were already established during the formation of LAGs, and who did not let much space for the integration of new actors, partly due to the (Wallonia specific) pre-proposal project 
selection. Keeping in mind the benefits that this policy brings - less bureaucracy, programming periods start on time contrarily to neighbouring countries, projects holders are confident that their funding is secured and can evolve without pressure... one could wonder about a more balanced relationship between the bottom-up and the top-down approach. Indeed, pushing LAGs into offering concrete projects to be selected in view of the EU call, might push them to hastily propose a strategy and projects, when the analysis and assessment of the previous period is not over and results might not be clear yet. This also limited the time that could be dedicated to concertation and hindered the creation of new partnerships in project 1 , by subsiding the same partner two periods in a row out of convenience. Maybe a better balance can be found while consolidating the advantages of the approach?

Where social and human capitals plainly activate potentialities, their lack of stability impairs the sustainability of the projects. The importance of the pool of volunteers to recruit from is underestimated but at the same time this means, once more, a mobilisation of social capital. One of the LAG coordinators put it very straight: "We could feel that some volunteers gave everything for six months and we can understand that they need to rest. When those want to take a break from the project, how do we do to find other people?" (Personal communication).

Finally, a lesson from these cases for all LEADER projects and for all development projects for that matter, might be to look at social capital as a dynamic process, rather than an "input" and/or "output" that can and should be measured. In their study on how to assess and improve collective action at tourism destinations, Rodriguez-Girón and Vanneste (2019) focus on 1) the function of the dimensions of social capital (networks, trust and collective action) and 2) the conditions to foster these functions. Let's not forget that SC "starts as a potential resource residing in the actor's networks at different levels and once norms and trust facilitate purposive interactions, SC becomes manifest...in the form of collective actions" (Rodriguez-Girón and Vanneste, 2019: 34). Conditions for networks to work or networking imply a balance between cooperation and competition and between interests from different stakeholder groups. Trust comes with mutual benefits and collectively acceptable behaviour but also with actions against those who do not comply while, finally, collective action is as strong as the strength of the collective. To create a strong collective, one needs to allocate resources such as skills, money and information and to foster leadership and (emotional) ownership. One has to recognize that such a process takes time - even a 7-year policy period for LEADER projects might not be enough if SC as an input is weak -, is subject of (positive and negative, right and incorrect) perceptions and suffers from unclear (i.e. difficult to measure) or unnoticed results and outcomes. Of course, the complexities are even higher than what we presented in this contribution. Beyond the basic set of SC dimensions, one can find organisation and communication on the one hand and social cohesion and inclusion on the other hand while SC within a community is not a closed system. In literature, one makes a distinction between different SC levels of scope (bonding, bridging, linking; Rodriguez-Girón and Vanneste, 2019) which means that our study can be considered as a pilot that invites for further analysis of more development projects, in more regions and covering more periods. 


\section{BIBLIOGRAPHY}

AUBERT F., PIVETEAU V. \& SCHMITT B. (2008), Politiques Agricoles et Territoires, Versailles, Ed. Quae.

BOURDIEU P. (1986), "The forms of capital”, Handbook of theory of research for the sociology of education, New York, Greenwood Press, J.E. Richardson (Ed.), pp. 46-58.

CAMAGNI R. (2008), “Regional competitiveness: towards a concept of territorial capital”, Modelling Regional Scenarios for the Enlarged Europe, Berlin-Heidelberg, Springer, pp. 33-47.

COLEMAN J.S. (1988), "Social capital in the creation of human capital”, American Journal of Sociology, 94, Supplement S95-S120, Chicago, The University of Chicago Press.

DG AGRI (2017), “Rural Development Policy 2007-13”, Europa, Retrieved on 3/02/2017 from https://ec.europa.eu/agriculture/rurdev_en.

DORÉ G. (2011), « Le programme européen LEADER a 20 ans : bilan et perspectives à partir du cas français ", Proceedings of the Fifth Days For Social Sciences Research, Dijon, Agrosup Dijon SFER-INRACIRAD.

EENRD and EC (2010), "Working paper on Capturing impacts of LEADER and of measures to improve Quality of Life in rural areas”, Rural Evaluation News, 5, Brussels, European Evaluation Helpdesk for Rural Development.

ENRD (2014), Rural Development Programmes 2007-2013, Progress Snapshot 2007-2013: BELGIUM, Brussels, ENRD Contact Point.

ENRD (2014), Rural Development Policy Overview: National and Regional Programmes, EC -ENRD EENRD, Retrieved on 28/06/2017 from http://enrd.ec.europa.eu/enrd-static/policy-in-action/ rural-development-policy-overview/national-and-regional-programmes/en/national-andregional-programmes_en.html.

ENRD (2015), “2014-2020 Rural Development Programme: Key facts \& figures - Belgium Flanders", Brussels, ENRD Contact Point.

ENRD (2017), “RDP Implementation”, Europa, Retrieved on 28/06/2017 from http:// enrd.ec.europa.eu/policy-in-action/rdp-implementation_e.

EUROPEAN COMMISSION (2005), “Council Regulation (EC) No 1698/2005 of 20 September 2005 on support for rural development by the European Agricultural Fund for Rural Development (EAFRD)", Official Journal of the European Union, Brussels, European Commission.

EUROPEAN COMMISSION (2017), “Agriculture and Rural Development: Previous rural development programming periods”, Europa, Retrieved on May 15 from https://ec.europa.eu/ agriculture/rural-development-previous/2007-2013_en.

EUROPEAN COMMISSION, DG AGRI - Unité C.4 (2017), Lignes directrices. Évaluation de la méthode LEADER/DLAL, Bruxelles, European Commission.

GERRETS A.M., DER ZEE E. \& VANNESTE D. (2015), “Communicate, incorporate and appreciate: the role of network managers in working towards a resilient tourism network", Proceedings: Heritage Tourism \& Hospitality: international conference 2015. 
GROOTAERT C., BASTELAER T. (2001), “Understanding and measuring social capital: a Synthesis of Findings and Recommendations from the Social Capital Initiative", Social Capital Initiative, Working Paper, 24, Washington, DC., World Bank.

GROOTAERT C., NARAYAN D., JONES V.N. \& WOOLCOCK M. (2004), "Measuring Social Capital. An Integrated Questionnaire”, World Bank Working Paper 18, Washington, DC, World Bank.

HANIFAN (1916), "The rural school community center", Annals of the American Academy of Political and Social Science, 67, London, Sage Publications, pp. 130-138.

HUFF R. (2013), “Human Capital”, Encyclopcedia Britannica, 2017, Retrieved on 25/06/2017 from https://www.britannica.com/topic/human-capital.

JOUEN M., KOLOSY K., PELLEGRIN J.-P., RAMSDEN P., SZEGVARI P. \& CHAMBON N. (2010), Soutenir le développement local dans le cadre de la politique de cohésion : bonne pratiques et options futures, Rapport pour la DG Regio, Sophia Antipolis, ADETEF.

LAG CUESTAS (2007), [Unpublished] Plan de Développement Stratégique, 131 p.

LAG HSFA (2008), [Unpublished] Plan de développement Stratégique du Parc Naturel de la Haute Sûre et de la Forêt d'Anlier, $101 \mathrm{p}$.

LAG PTC (2008), [Unpublished] Dossier de Candidature du Groupe d'Action Locale Assesse-Gesves-Ohey, $138 \mathrm{p}$.

LATOUR B. (2005), Reassembling the Social: An Introduction to Actor-Network Theory, New York, Oxford University Press.

LATOUR B. (2010), “An Attempt at a 'Compositionist Manifesto”, New Literary History, 41, 3, Baltimore, Johns Hopkins University Press, pp. 471-490.

LEVIEN M. (2015), “Social Capital as Obstacle to Development: Brokering Land, Norms, and Trust in Rural India”, World Development, 74, Edinburgh, Elsevier, pp. 77-92.

LHERMITE K. (2000), “Identity and rurality in Flanders", Claiming Rural identities - dynamics, contexts, policies, Assen, Haartsen, Tialda, Van Gorcum, pp. 36-44.

MARTÍNEZ ARROYO F., SACRISTÁN LÓPEZ H. \& YAGÜE BLANCO J.-L. (2015), “Are local action groups, under LEADER approach, a good way to support resilience in rural areas?", AGER, Madrid, CEDDAR, pp. 39-63.

OAKLEY P. (1991), Projects with people: The practice of participation in rural development, Geneva, International Labour Office.

OECD (2006), The New Rural Paradigm: Policies and Governance, Paris, OECD Publishing.

OECD (2017), Social Economy 2017, Retrieved on 25/07/2017 from http://www.oecd.org/cfe/leed/ social-economy.htm.

PERMINGEAT M. (2017), [Unpublished thesis] Social and human capitals in European Rural Development projects - Three LEADER projects in Wallonia analysed, Leuven.

PIKE A., RODRIGUEZ-POSE A. \& TOMANEY J. (2010), “What Kind of Local and Regional Development and for Whom?”, Regional Studies, 41, 9, Abingdon, David Bailey pp. 1253-1269.

PISANI E., FRANCESCHETTI G., SECCO L. \& CHRISTOFOROU A. (2017), Social Capital and Local Development: From Theory to Empirics, Basingstoke, Springer International Publishing, Palgrave Macmillan. 
PUTNAM R. (1995), “Bowling alone: America's declining social capital”, Journal of Democracy, 6, 1, Baltimore, Johns Hopkins University Press, pp. 65-78.

REISSMAN L. (1964), The Urban Process, New York, Free Press.

RODRIGUEZ-GIRON S., VANNESTE D. (2019), "Social capital at the tourist destination level: Determining the dimensions to assess and improve collective action in tourism", Tourist Studies, 19, 1, London, Sage Publications, pp. 23-42.

RWDR (2014), Projets 2007-2013 - Le réseau wallon de Développement Rural, February 27, 2014, Retrieved on 24/05/2017 from http://www.reseau-pwdr.be/project/le-r\%C3\%A9seau-wallon-ded\%C3\%A9veloppement-rural.

SHEPHERD A. (1998), Sustainable Rural Development, Basingstoke, Palgrave Macmillan.

STATISTICS BELGIUM (2010), Structure de la population selon le lieu de résidence : superficie et densité, 2017, Belgian Federal Government, Retrieved on 1/08/2017 from http://statbel.fgov.be/fr/ statistiques/chiffres/population/structure/residence/superdense.

VANNESTE D., RYCKAERT L. (2011), "Networking and Governance as Success Factors for Rural Tourism? The Perception of Tourism Entrepreneurs in the Vlaamse Ardenne", BSGLg, Liège, Université de Liège, pp. 53-71.

VANNESTE D., RYCKAERT L (2012), “Governance in the Tourism Practice. Entrepreneurial Attitudes”, in FAYOS-SOLAS E., ALBINO MATOS DE SILVA J. \& JAFARI J. (eds.), Knowledge Management in Tourism: Policy and Governance Applications, Series Bridging Tourism Theory and Practice, 4, Chapter 16, Bingley (UK), Emerald, pp. 303-323.

VILLAGE MAGAZINE (2016), Le Pouvoir des Campagnes, Hors-série n¹, octobre 2016, Saint-Paul (France), Acteur Rural.

\section{NOTES}

1. Bastogne (2017) http://www.bastogne.be/loisirs/bottin-des-associations, Commune d'Assesse (2017) http://www.assesse.be, Commune d'Ohey (2017) http://www.ohey.be, Commune de Gesves (2017) http://www.gesves.be, Etalle (2017) http://www.etalle.be/accueil.html, Habay (2017) http://www.habay.be, Léglise (2017) http://www.communeleglise.be, Martelange - commune frontalière (2017) http://www.martelange.be, Tintigny (2017) http://www.tintigny.be/, Vauxsur-Sûre (2017), http://www.vaux-sur-sure.be

\section{ABSTRACTS}

This article investigates the role in practice of social capital in the success and perennity of European rural development projects, taking three Walloon LEADER projects as case studies. In the context of rural areas, that carry innate characteristics - proximity, sense of community social capital is expected to play an important role in the success or failure of development projects. Yet, in theory, social capital is mentioned by the European Commission only when referring to outputs of the approach, never as an input. By investigating three LEADER projects 
that were developed between 2007 and 2013 in Wallonia through qualitative analysis, from the conception of the Local Development Strategy to the current situation of projects - more than 5 years after the end of funding - we confirmed the significance of trust as a lever for development, highlighted the importance of human capital and discussed the relevance of project time-scales.

Cet article examine le rôle réel du capital social dans le succès et la pérennité des projets européens de développement rural, en prenant trois cas d'études LEADER développés en Wallonie comme exemple. Dans le contexte des zones rurales, qui comportent des caractéristiques originales (proximité, sentiment de collectivité), il est attendu que le capital social joue un rôle important dans le succès ou l'échec des projets de développement. En théorie cependant, le capital social n'est mentionné par la Commission Européenne que lorsqu'il s'agit des résultats des projets, jamais lorsqu'il ne s'agit d'intrants. A travers l'analyse qualitative de trois projets ayant eu lieu sur la période de programmation 2007 et 2013, de la conception du Plan de Développement Stratégique à la situation actuelle des projets (plus de cinq ans après la fin du financement européen), nous confirmons l'importance de la confiance comme levier de développement, mettons en valeur celle du capital humain nécessaire pour le bon développement des projets, et discutons la pertinence de l'échéancier des projets.

\section{INDEX}

Keywords: LEADER approach, rural development, rural policies, participation, social capital, human capital, Wallonia (Belgium)

Mots-clés: LEADER-DLAL, développement rural, politiques rurales, participation, capital social, capital humain, Wallonie (Belgique)

\section{AUTHORS}

\section{MARIE PERMINGEAT}

Fellowship Administrator, Forward Institute, London, mariepermingeat@gmail.com.

\section{DOMINIQUE VANNESTE}

Associate professor, University of Leuven, Division of Geography \& Tourism, dominique.vanneste@kuleuven.be 